International Journal of Engineering Technology and Scientific Innovation

ISSN: 2456-1851

Volume: 06, Issue: 03 "May-June 2021"

\title{
REMINERALIZATION OF THE ENAMEL STRUCTURE AFTER A CHEMICAL ATTACK BY USING REMIN PRO® COMMERCIAL PASTE
}

\author{
Stephanie Partida Vanoni ${ }^{1}$, José Macario Hernández Izaguirre ${ }^{2}$, \\ Francisco Javier Llamas Del Olmo², Yadira Barreto Orta², \\ Mario Alberto Palomares Rodríguez ${ }^{2} \&$ Rogelio Oliver Parra ${ }^{2}$ \\ ${ }^{1}$ Graduate in Dental Surgeon, M.D, of the Dentistry Faculty, Autonomous University of Tamaulipas. \\ ${ }^{2}$ Professor of the Dentistry Faculty, Autonomous University of Tamaulipas.
}

DOI: https://doi.org/10.51193/IJETSI.2021.6301

\begin{abstract}
Tooth whitening has become one of the most frequently requested dental procedures by the public. The public has come to demand whiter, more perfect smiles and in response many choices for tooth whitening have been made available. These include home-based products such as toothpastes, gels, and films, as well as in-office based systems where products containing highly concentrated bleaching agents are applied under professional supervision. Materials and methods: 30 specimens were selected based on the color results using the Vita EasyShade ${ }^{\circledR}$ brand spectrophotometer, in order to have a 3M3 A3.5 color standard set with 16 specimens. Results: By means of the characterization techniques of Scanning Electron Microscopy (SEM) and Energy Dispersive Spectrometry (EDS), it was demonstrated when comparing the results of the elemental analysis that the percentage of calcium present in the control sample was lower compared to the tooth sample. Conclusion: Tooth whitening with 38\% Opalasense Boost ${ }^{\circledR}$ affects the enamel structure leaving marked cracks on the entire surface causing a great loss of minerals, the above was analyzed by means of scanning electron microscopy (SEM) and Energy Dispersive Spectroscopy (EDS).
\end{abstract}

Keywords: Enamel, Remineralization, Bleaching, Hydrogen peroxide.

\section{INTRODUCTION}

Facial aesthetics associated with teeth has preoccupied society since ancient times. The fear of social rejection due to changes in shape, color or dental positions, can have a great psychological impact on patients. Currently, the demand for aesthetics has made tooth whitening one of the most associated dental therapies. Dental whitening continues to become popular among the 
International Journal of Engineering Technology and Scientific Innovation

ISSN: 2456-1851

Volume: 06, Issue: 03 "May-June 2021"

population, therefore it is vitally important that dentists are trained to know how to handle whitening agents following a diagnostic protocol, treatment plan and maintenance, in addition to knowing in depth the indications and contraindications of each one of the existing techniques on the market, as well as its advantages and disadvantages and timely information to the patient ${ }^{(1-2)}$.

The tooth whitening technique was first described in 1848 using oxalic acid, followed by the introduction of the vital night-time whitening technique in $1989^{(2)}$.

In 1931, Bruce Clark was the first to subject natural teeth to scientific color measurement and analysis and expressed the importance of color dimensions. It is important to understand and keep in mind that this concept includes three dimensions that determine it. Thus, color is the set of tint, value and intensity. Of the three components, the value (also called lightness or brightness) is the most influential, followed by chroma (also called saturation or intensity) and lastly the hue or hue. Nearly eighty years ago Clark wrote: "Color, like shape, has three dimensions, but they are not in general use. Many of us do not even know their names, nor their measurement scales"(3). In other words, we as dentists have not been educationally equipped to deal with the problem of color. Color is an essential ingredient in our environment and is associated with certain feelings, emotions, and meanings. These associations are defined both by culture and by our own experiences. Color conveys emotion and affects energy producing an emotional impact that can delight or distress ${ }^{(3-4)}$.

In 1991 they conducted a review of the studies published until then on the effects and safety of home vital whitening with splints and concluded that the safety it offers is similar to that of other dental whitening procedures provided it is carried out correctly. This technique has become one of the most used today; It is indicated as a single treatment in cases of mild or moderate discoloration and also as a complement to a whitening technique in the office, in this case we speak of combined whitening. Although in its beginnings $10 \%$ carbamide peroxide was used as a bleaching agent, currently there is a wide variety of products with higher concentrations (between $15 \%$ and $30 \%$ ) or that, instead of this agent, use peroxide of Hydrogen at low concentration (between $3.5 \%$ and $10 \%)^{(5-6)}$.

In 2003, the ADA conducted a survey about tooth whitening and a record that more than 1000 adults ask their dentists about tooth whitening, which is why it is of considerable importance to be able to offer this treatment to our patients. Patients who wish to whiten their teeth can choose from three basic types of treatments to whiten their teeth, either professionally applied by the dentist in the dental office, applied at home with professionally pre-made guards respecting the gingival anatomy, or those applied and purchased by themsame in any store ${ }^{(6-7)}$. 
Since 1880, aesthetics has been an important topic in dentistry and has been accompanied not only by different types of dental restorations but also by bleaching oxidizing substances. The dentists were good chemists and were in charge of preparing and mixing the biomaterials applied in the office. Klusmier in 1960 described for the first time the technique for ambulatory whitening in vital teeth, which consisted of loading an acetate tray with bleaching material and bringing it to the mouth overnight, and which was popularized in 1996 as the tray 5 technique. Clinical studies reveal that at least $60 \%$ of the whitening agent (10\% carbamide peroxide) gel applied in the whitening tray remains active 4 hours after its start, which supports the continuous night use of the splint. Other studies such as the CRA, affirm that after 2 hours only $20 \%$ of the initial activity remains) ${ }^{(7-8)}$.

In any case, it is advisable to renew the bleaching agent 3 times every hour, but if this is not possible, its use, without replacement, only during sleep, has been shown to be effective ${ }^{(9)}$.

\section{MATERIALS AND METHODS}

To carry out the present investigation, it was necessary to select teeth extracted for completely healthy orthodontic reasons in a period of no more than 3 months. In order to have a correct selection, a cleaning was carried out with an Ultrasonic Scaler ${ }^{\circledR}$ brand cavitron.

30 specimens were selected based on the color results using the Vita EasyShade ${ }^{\circledR}$ brand spectrophotometer, in order to have a 3M3 A3.5 color standard set with 16 specimens (Fig. 1). Once the 16 standardized specimens were obtained in the same color, they were divided into two groups: a control group and an experimental group, each consisting of 8 teeth, all teeth were placed in deionized water (RA $®$ brand) until the experiment is carried out.
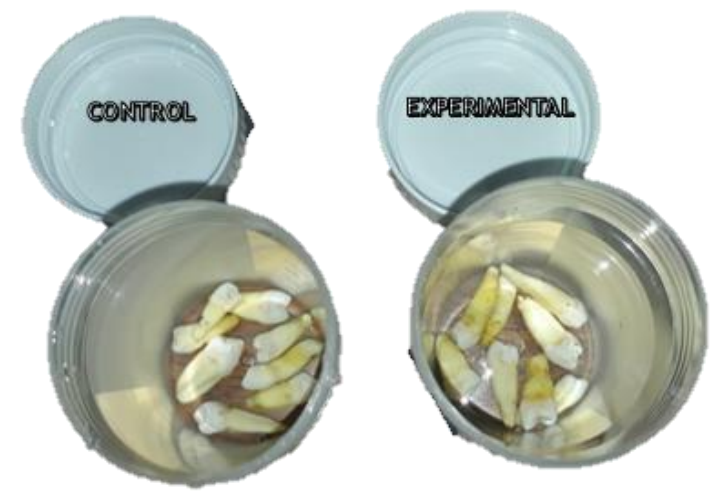

Fig. 1: Division of groups made up of 8 teeth each.

To continue with the methodology, the following stages were followed: 
Stage 1. Each group of teeth was seeded in a Putty Speedex Coltene ${ }^{\circledR}$ brand condensation silicone base, leaving the crown exposed and taking the buccal aspect of each tooth to perform the necessary tests (Fig. 2).
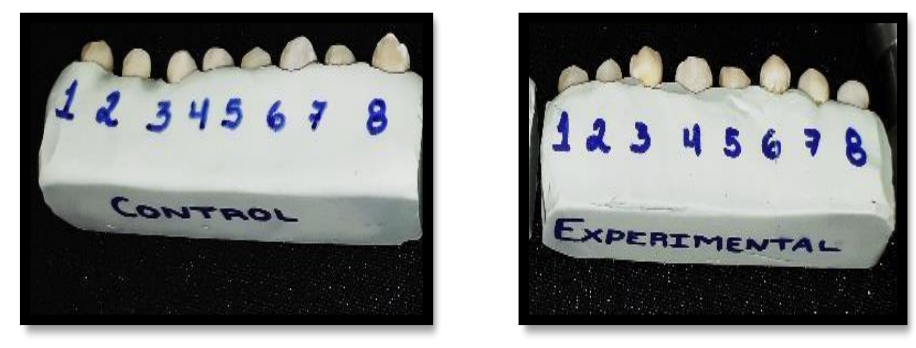

Fig. 2: Teeth sown in condensation silicone and numbered for study.

Stage 2. Both groups were printed with an acetate slide to later mark the midpoint of each tooth with the help of a vernier and also open a reference point with the help of a scalpel to take the color change measurements periodically.

Stage 3. Both groups of teeth were polished in order to prepare the surface to be worked on later. This was done with the low-speed piece with contra-angle, brush and prophylactic paste. At the end, each piece was washed and dried with the help of the triple syringe.

Stage 4. In this stage, the bleaching was applied using 38\% Opalacense Boost ${ }^{\circledR}$ to both groups, always following the manufacturer's specifications (Fig. 3).
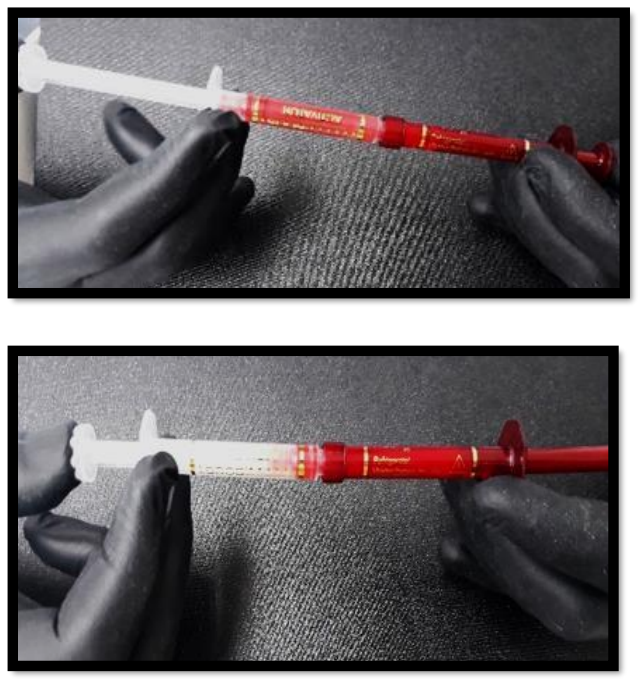

Fig. 3: Bleaching mixture in the dispersion syringes. 
International Journal of Engineering Technology and Scientific Innovation

ISSN: 2456-1851

Volume: 06, Issue: 03 "May-June 2021"

Stage 5. Color registration was re-determined using the Vita EasyShade ${ }^{\circledR}$ brand spectrophotometer to have color registration immediately after bleach application.

Stage 6. A commercial Remin Pro® paste containing hydroxyapatite was applied to the experimental group with the help of a toothbrush. Each tooth was brushed for a period of 1 minute and at the end washed with plenty of water.

Stage 7. At the end of the application of the commercial Remin Pro® toothpaste, the teeth were dried. Subsequently, the color record of this group was taken again to observe and document the changes.

Stage 8. Both groups (control and experimental) were placed in a container until the necessary tests were carried out.

Stage 9. To the experimental group of teeth, commercial Remin Pro® paste was applied every 12 hours and a specimen was taken at 3,7 and 14 days. The samples were analyzed by Scanning Electron Microscopy (SEM) at the Technologic Institute of Madero City in Tamaulipas, Mexico - Petrochemical Research Center. To carry out the tests with the scanning microscope, it was necessary to section the tooth first by removing the root and pulp with the help of a micro motor and flexible disc and for the pulp by means of endodontic files, to later section the crown in half by performing a cross section.

\section{RESULTS}

By means of the characterization techniques of Scanning Electron Microscopy (SEM) and Energy Dispersive Spectrometry (EDS), it was demonstrated when comparing the results of the elemental analysis that the percentage of calcium present in the control sample was lower compared to the tooth sample. Therefore, the loss of minerals in the enamel structure is associated with the chemical attack carried out and the increase of this element in the daily use of Remin Pro ${ }^{\circledR}$ paste, which suggests that its constant use returns minerals in the enamel structure. (Table 1-2), (Fig 4-5). 
International Journal of Engineering Technology and Scientific Innovation

ISSN: 2456-1851

Volume: 06, Issue: 03 "May-June 2021"

Table 1: Post-registration when applying Remin Pro ${ }^{\circledR}$ to (A) Control group.

\begin{tabular}{|c|c|c|c|c|c|}
\hline \multicolumn{6}{|c|}{$\begin{array}{l}\text { (A) CONTROL } \\
\text { GROUP }\end{array}$} \\
\hline No. & Inicial & $\begin{array}{l}\text { Inmediate } \\
\text { Whitening }\end{array}$ & $\begin{array}{c}3 \\
\text { Hours }\end{array}$ & $\begin{array}{c}7 \\
\text { Hours }\end{array}$ & $\begin{array}{c}14 \\
\text { Hours }\end{array}$ \\
\hline 1 & $\begin{array}{l}3 \mathrm{M} 3 \\
\mathrm{~A} 3.5\end{array}$ & 2M3 B3 & $\begin{array}{l}2 \mathrm{R} 2.5 \\
\mathrm{~A} 2\end{array}$ & $\begin{array}{c}2 \mathrm{M} 2 \\
\mathrm{~A} 3\end{array}$ & $\begin{array}{c}2 \mathrm{M} 3 \\
\mathrm{~B} 3\end{array}$ \\
\hline 2 & $\begin{array}{l}3 \mathrm{M} 3 \\
\mathrm{~A} 3.5\end{array}$ & 2M3 B3 & $\begin{array}{l}2 \mathrm{M} 2 \\
\mathrm{~A} 2\end{array}$ & $\begin{array}{l}2 \mathrm{M} 2 \\
\mathrm{~B} 2\end{array}$ & $\begin{array}{c}2 \mathrm{M} 2 \\
\mathrm{~A} 3\end{array}$ \\
\hline 3 & $\begin{array}{l}3 \mathrm{M} 3 \\
\mathrm{~A} 3.5\end{array}$ & 2M3 B3 & $\begin{array}{l}2 \mathrm{M} 2 \\
\mathrm{~A} 2\end{array}$ & $\begin{array}{c}2 \mathrm{M} 2 \\
\mathrm{~B} 2\end{array}$ & $\begin{array}{c}2 \mathrm{M} 2 \\
\mathrm{~B} 2\end{array}$ \\
\hline 4 & $\begin{array}{l}3 \mathrm{M} 3 \\
\mathrm{~A} 3.5\end{array}$ & $1 \mathrm{M} 2 \mathrm{~B} 2$ & $\begin{array}{c}2 \mathrm{R} 1.5 \\
\mathrm{~A} 2\end{array}$ & $\begin{array}{c}2 \mathrm{M} 2 \\
\mathrm{~B} 2\end{array}$ & $\begin{array}{l}2 \mathrm{M} 1 \\
\mathrm{~A} 1\end{array}$ \\
\hline 5 & $\begin{array}{l}3 \mathrm{M} 3 \\
\mathrm{~A} 3.5\end{array}$ & 1M2 A3 & $\begin{array}{l}2 \mathrm{M} 2 \\
\mathrm{~A} 3\end{array}$ & $\begin{array}{c}2 \mathrm{M} 2 \\
\mathrm{~B} 2\end{array}$ & $\begin{array}{c}2 \mathrm{M} 2 \\
\mathrm{~A} 3\end{array}$ \\
\hline 6 & $\begin{array}{l}3 \mathrm{M} 3 \\
\mathrm{~A} 3.5\end{array}$ & 3M3 A3.5 & $\begin{array}{c}2 \mathrm{R} 2.5 \\
\mathrm{~A} 3\end{array}$ & $\begin{array}{c}2 \mathrm{M} 2 \\
\mathrm{~B} 2\end{array}$ & \\
\hline 7 & $\begin{array}{l}3 \mathrm{M} 3 \\
\mathrm{~A} 3.5\end{array}$ & 2M3 B3 & $\begin{array}{l}2 \mathrm{M} 2 \\
\mathrm{~A} 2\end{array}$ & $\begin{array}{c}2 \mathrm{M} 2 \\
\mathrm{~B} 2\end{array}$ & $\begin{array}{c}1 \mathrm{M} 2 \\
\mathrm{~A} 3\end{array}$ \\
\hline 8 & $\begin{array}{l}3 \mathrm{M} 3 \\
\mathrm{~A} 3.5\end{array}$ & 2M3 B3 & $\begin{array}{c}2 \mathrm{R} 2.5 \\
\mathrm{~A} 2\end{array}$ & $\begin{array}{c}2 \mathrm{M} 2 \\
\mathrm{~B} 2\end{array}$ & \\
\hline
\end{tabular}

Table 2: Post-registration when applying Remin Pro $₫$ to (B) Experimental group.

\begin{tabular}{|c|c|c|c|c|c|}
\hline \multicolumn{7}{|c|}{ (B)EXPERIMENTAL GROUP } \\
\hline No. & Inicial & $\begin{array}{c}\text { Inmediate } \\
\text { Whitening }\end{array}$ & $\begin{array}{c}\mathbf{3} \\
\text { Hours }\end{array}$ & $\begin{array}{c}\mathbf{7} \\
\text { Hours }\end{array}$ & $\begin{array}{c}14 \\
\text { Hours }\end{array}$ \\
\hline $\mathbf{1}$ & $3 \mathrm{M} 3$ & $2 \mathrm{M} 3 \mathrm{~B} 3$ & $2 \mathrm{M} 2$ & $2 \mathrm{M} 2$ & \\
& $\mathrm{~A} 3.5$ & & $\mathrm{~A} 2$ & $\mathrm{~A} 2$ & \\
\hline $\mathbf{2}$ & $3 \mathrm{M} 3$ & $2 \mathrm{M} 3 \mathrm{~A} 3$ & $2 \mathrm{M} 2$ & $2 \mathrm{M} 2$ & $2 \mathrm{M} 3$ \\
& $\mathrm{~A} 3.5$ & & $\mathrm{~A} 2$ & $\mathrm{~A} 2$ & $\mathrm{~B} 3$ \\
\hline $\mathbf{3}$ & $3 \mathrm{M} 3$ & $2 \mathrm{M} 3 \mathrm{~B} 3$ & $2 \mathrm{M} 2$ & $2 \mathrm{M} 2$ & $2 \mathrm{M} 2$ \\
& $\mathrm{~A} 3.5$ & & $\mathrm{~A} 2$ & $\mathrm{~A} 2$ & $\mathrm{~A} 2$ \\
\hline $\mathbf{4}$ & $3 \mathrm{M} 3$ & $2 \mathrm{M} 3 \mathrm{~B} 3$ & $2 \mathrm{M} 2$ & $2 \mathrm{M} 2$ & $2 \mathrm{M} 2$ \\
& $\mathrm{~A} 3.5$ & & $\mathrm{~A} 2$ & $\mathrm{~A} 2$ & $\mathrm{~A} 3$ \\
\hline $\mathbf{5}$ & $3 \mathrm{M} 3$ & $1 \mathrm{M} 2 \mathrm{~A} 3$ & $2 \mathrm{M} 2$ & $2 \mathrm{M} 2$ & $2 \mathrm{M} 2$ \\
& $\mathrm{~A} 3.5$ & & $\mathrm{~A} 2$ & $\mathrm{~A} 2$ & $\mathrm{~A} 2$ \\
\hline $\mathbf{6}$ & $3 \mathrm{M} 3$ & $2 \mathrm{M} 3 \mathrm{~A} 3.5$ & $2 \mathrm{M} 3$ & $2 \mathrm{M} 2$ & \\
& $\mathrm{~A} 3.5$ & & $\mathrm{~B} 3$ & $\mathrm{~A} 2$ & \\
\hline
\end{tabular}


International Journal of Engineering Technology and Scientific Innovation

ISSN: 2456-1851

Volume: 06, Issue: 03 "May-June 2021"

\begin{tabular}{|c|c|c|c|c|c|}
\hline $\mathbf{7}$ & $3 \mathrm{M} 3$ & $2 \mathrm{M} 3 \mathrm{~B} 3$ & $2 \mathrm{M} 2$ & $2 \mathrm{M} 2$ & $2 \mathrm{M} 2$ \\
& $\mathrm{~A} 3.5$ & & A2 & A2 & A3 \\
\hline $\mathbf{8}$ & $3 \mathrm{M} 3$ & $2 \mathrm{M} 3 \mathrm{~B} 3$ & $2 \mathrm{M} 2$ & $2 \mathrm{M} 2$ & $2 \mathrm{M} 2$ \\
& $\mathrm{~A} 3.5$ & & A2 & A2 & A2 \\
\hline
\end{tabular}

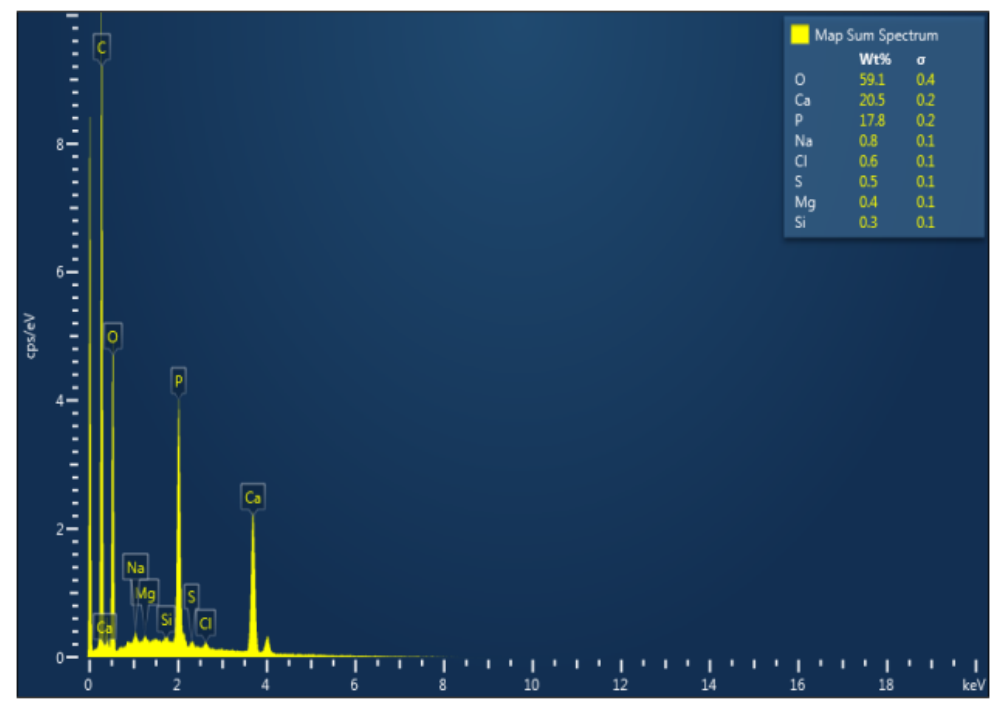

Fig. 4: Elemental analysis of the control sample.

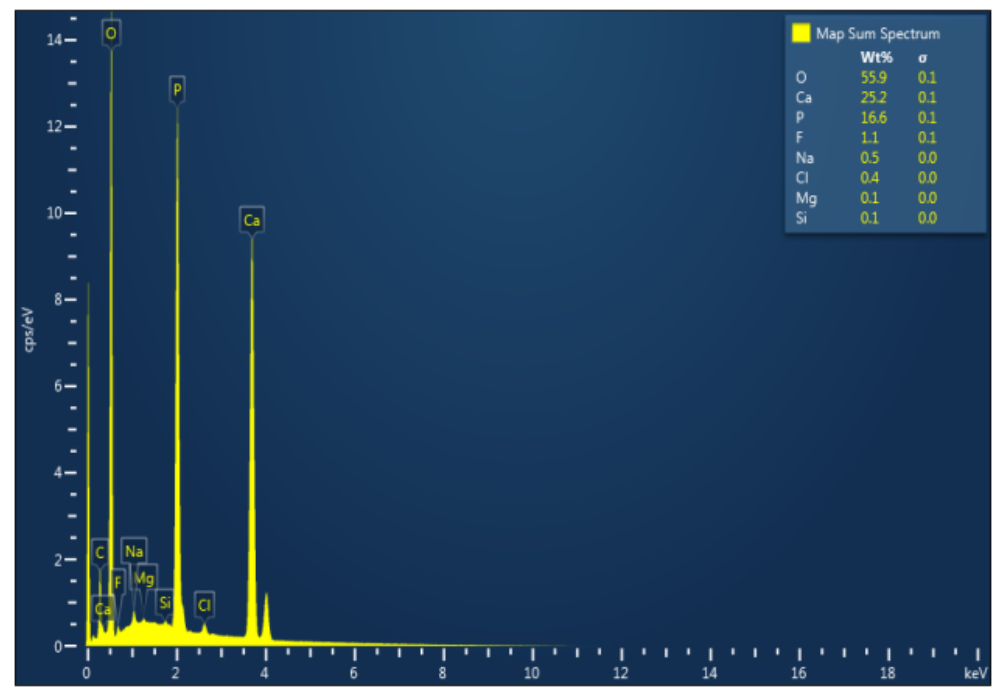

Fig. 5: Elemental analysis of the experimental sample. 


\section{DISCUSSION}

Several years ago, a dental whitening treatment in the office was carried out with very little supporting research, currently it has become one of the fastest growing dental areas, thanks to the high demand of patients who go to a dental office in search of an aesthetic and healthy smile. In a large majority of people, their dental appearance will greatly influence when assessing their facial beauty, which can be affected by coloration and staining of their teeth 2 . For this reason, it was of the utmost importance to first demonstrate the damage caused by these chemical agents to our teeth, but also remineralize the dental structure in order to turn this new trend into not only that, but also into a treatment that, in addition to being an aesthetic treatment, is functional ${ }^{(9-10)}$. Currently, the most used whitening techniques for vital teeth are the outpatient technique that uses carbamide peroxide in low concentrations and the office technique that uses hydrogen peroxide in high concentrations that may or may not be activated with catalytic equipment such as lamps. light curing and argon laser ${ }^{(7)}$.

Generally, in vivo and in vitro whitening studies for vital teeth only consider the outpatient technique, varying the different concentrations of the whitening agent, while few studies evaluate the techniques in the office. The published results on the ability to whiten teeth with the ambulatory technique and the one activated with argon laser are satisfactory, however studies comparing the efficacy and stability of the two techniques are limited. With the high technological development, more and more substances and procedures are applied in dentistry without scientific evidence to guarantee them ${ }^{(5)}$.

Despite the satisfactory results obtained with this technique, immune investigations have revealed problems such as burns and alteration of soft tissues, dental hypersensitivity and modifications of the dental structure, in addition to a significant decrease in adherence values. To improve adhesion after whitening, it is suggested to postpone the restorative treatment for two to three weeks ${ }^{(6)}$.

Another proposed theory is that in enamel pores, dentin and dentin fluid function as a peroxide / oxygen reservoir, resulting in a concentration of oxygen on the enamel surface, completely inhibiting the polymerization of some resins. It is known that the longer the exposures time with hydrogen peroxide, the greater the penetration depth of the oxygen. A period of more than three weeks is required for the bond strength to return to the values obtained in unbleached enamel, although there is remineralization by saliva that reverses the changes. Methods have been proposed to eliminate the clinical problems caused by the decrease in the adhesion strength of the resins to the tooth after whitening; the most common recommendation is to delay the adhesive procedure for 24 hours, a week or up to three weeks ${ }^{(7-8)}$. 
International Journal of Engineering Technology and Scientific Innovation

ISSN: 2456-1851

Volume: 06, Issue: 03 "May-June 2021"

\section{CONCLUSION}

Tooth whitening with 38\% Opalasense Boost ${ }^{\circledR}$ affects the enamel structure leaving marked cracks on the entire surface causing a great loss of minerals, the above was analyzed by means of scanning electron microscopy (SEM) and Energy Dispersive Spectroscopy (EDS), the results obtained reflected the presence of minerals such as calcium, oxygen, phosphorus, fluorine and sodium. According to the study on the effectiveness of the experimental group after brushing with Remin Pro ${ }^{\circledR}$ commercial toothpaste, it was shown that there is an almost total recovery of the amount of minerals lost during the whitening process caused by the chemical attack.

According to the results obtained, it is possible to conclude that the application of Remin Pro ${ }^{\circledR}$ commercial paste containing hydroxyapatite can be one of the treatments that helps to reverse the effects caused by the application of a chemical agent such as which directly damages the structure of the enamel. Through the use of commercial Remin Pro ${ }^{\circledR}$ paste it is possible to reverse its demineralizing effect to a certain degree, solving not only the dental aesthetics of patients but also improving the topography of the tooth avoiding damage to the enamel surface.

\section{BIBLIOGRAPHY}

1. Berga Caballero, A., Forner Navarro, L. y Amenguar Lorenzo, J. "Evaluación in vivo de los efectos del peróxido de carbamida al $10 \%$ y del peróxido de hidrógeno al $3,5 \%$ sobre la superficie del esmalte", Odontología Clínica, 2008:1; 6-9.

2. Casas Tola, N. A., Quiroga Castro, C. G. y Zeballos López, L. "Blanqueamiento dental con láser", Rev Act Clin ,2012: 22; 1141-1146.

3. Clark, B. E. “An Analysis of Tooth Color”, J Am Dent Assoc ,1931: 18(11); 2093-2103.

4. Gueorguivea, M. P. "Efectos clínicos y estructurales del blanqueamiento dental", Odontol Sanmarquina, 2005: 8(2) ; 34-36.

5. Melo, N. et al. "Blanqueamiento vital y métodos para la valoración de su eficacia y estabilidad", CES Odontología, 2006:19(2) ; 53-60.

6. Miranda Zárate, A. M. et al."Efectos de un blanqueamiento dental con ozono y otro con Peróxido de Carbamida al 22\% sobre la fuerza de adhesión al esmalte en diferentes intervalos de tiempo", Act Odntol Venez, 2009: 47(4) ; 1-9.

7. Ortíz Aguilar, M. et al. "Efecto del blanqueamiento y el remineralizante sobre la microdureza y micromorfología del esmalte dental", Revista ADM, 2016: 73(2); 81-87. 
International Journal of Engineering Technology and Scientific Innovation

ISSN: 2456-1851

Volume: 06, Issue: 03 "May-June 2021"

8. Otero Baxter, Y. y Seguí Ulloa, A. "Las afecciones estéticas: un problema para prevenir", Rev Cubana Estomatol, 2001: 39(2) ; 83-9.

9. Roesch Ramos, L. et al. “Tipos y técnicas de blanqueamiento dental.”, Oral Revista, 2007: 8(25); 392-395.

10. Rosenstiel, S., Land, M. y Fujimoto, J. "Description of color, color-replication process, and esthetics", en Louis, S. (ed.). Mosby, 2006:709-39. 